Aronson, P. (2008). Breaking barriers or locked out? Class-based perceptions and experiences of postsecondary education. In J. T. Mortimer (Ed.), Social class and transitions to adulthood. New Directions for Child and Adolescent Development, 119, 41-54.

\title{
Breaking Barriers or Locked Out? \\ Class-Based Perceptions and \\ Experiences of Postsecondary \\ Education
}

\section{Pamela Aronson}

\begin{abstract}
This article provides an overview of objective and subjective class differences in experiences of postsecondary education. Using the metaphor of a funnel, it argues that cumulative disadvantage results when first-generation and lowincome college students are disproportionately filtered out at each stage of the postsecondary education process. Subjective class differences largely serve to reproduce existing inequalities, although the potential for transformation exists. This article considers inequalities during childhood and the transition to adulthood, stratification within institutions, and class differences in postsecondary educational enrollment, attendance, college life, work, financial aid, and attainment. Directions for future research and program and policy interventions are outlined. () Wiley Periodicals, Inc.
\end{abstract}

I thank Jeylan Mortimer and Ronald Aronson for comments on previous versions of this chapter and Laura Freeman for her development of the concept of a funnel as it applies to military enlistment and social capital. 
W

hether young people go on to college and the type of postsecondary education they pursue is a class-based process. Youth from poor or working-class backgrounds and those whose parents did not attend college are disproportionately likely to drop out of high school, end their educations at the high school level, enter community college or vocational programs, or have difficulty completing a bachelor's degree. In this chapter, I suggest that we can picture class differences in college pathways as shaped by a funnel that disadvantages and filters out deprived young adults at each stage of the postsecondary education process. Class-based differences also emerge in the subjective interpretations of the goals and outcomes of postsecondary education, which can reproduce or begin to transform inequalities.

\section{Starting Out Unequal: Theories of Class Differences in Education}

Class differences in education begin early in the life course and include differential childhood opportunities, access to resources, beliefs and worldviews, networks, and parental socialization. Schools act as sorting mechanisms that perpetuate inequalities intergenerationally (MacLeod, 1995) as children are socialized to assume a particular place in the class structure through practices such as academic tracking, gatekeeping by teachers and guidance counselors, differential supervision of students, and expectations of conformity (Bowles \& Gintis, 1976). Schooling produces workers who accept their own alienation and, through instilling beliefs in meritocracy, perpetuates the dominance of some groups over others (Turner, 1960; MacLeod, 1995).

Within educational institutions, middle-class job skills such as verbal competency are valued over working-class job skills, such as those applied in manual labor (Bourdieu, 1973). The attitudes, aspirations, and worldviews of the working class (their habitus, or internalization of objective circumstances) do not allow them access to the dominant cultural system created by the elite and rewarded in schools (Bourdieu, 1973). Early differences are exacerbated as children with more cultural capital are "better able to decode the implicit "rules of the game" to their advantage (Aschaffenberg \& Maas, 1997, p. 573). Advantaged parents' "self interested" practices "defend and further their class interests" (Ball \& Vincent, 2001, p. 181), such as advocating tracking schemes that help their own children (McGrath \& Kuriloff, 1999). Linguistic subcultures learned in the family (affecting whether children are taught to question or defer to authority figures) advantage middle-class children, who grow up with a greater sense of entitlement and confidence than their less advantaged peers (Lareau, 2003). Experiences linked to social class origin result in clearly unequal chances as young people make the transition to adulthood. 


\section{Inequalities in the Transition to Adulthood}

A rapidly changing global economy has resulted in an insecure employment market, deteriorating opportunities (Hill \& Yeung, 1999), a decline in lifelong occupational careers, and recognition that career trajectories are often unstable (Moen \& Orrange, 2002). One result is increasing educational attainment as young people attempt to improve their competitive position: 80 percent of Americans over age twenty-five now hold a high school diploma, over half have attained some college, and nearly one-quarter hold at least a bachelor's degree (U.S. Census Bureau, 2003). Young people who do not attend college are often relegated to the secondary labor market in jobs that are low paying, routine, and menial (Hill \& Yeung, 1999). There is a widening gulf in opportunities between young adults with more education and skills and those with less, especially poor and minority young adults (Tanner \& Yabiku, 1999). Some working-class youth respond to a lack of educational promise by investing in early work experience; they obtain higher-paying, more rewarding, and also more demanding and stressful jobs while they are still in high school (Mortimer, 2003). Because college delays the entry into adult work and family roles (Pallas, 1993), working-class youth typically make the transition to adulthood more rapidly than middle-class youth do (Furstenberg, Kennedy, McLoyd, Rumbaut, \& Settersten, 2004).

\section{Class Differences in the Objective Experiences of Postsecondary Education}

Today nearly three-quarters of undergraduates at all types of postsecondary institutions are nontraditional in terms of one or more of the following characteristics: not enrolling immediately after high school, part-time attendance, full-time work, financial independence from their parents, parenthood, or general equivalency diploma rather than high school diploma completion (Choy, 2002). Low-income students are more likely to delay college enrollment, with even a one-year delay after high school resulting in a lower likelihood of degree completion (Bozick \& DeLuca, 2005). The timing of enrollment is also associated with occupational attainment, marital stability, early parenthood, welfare dependency (Pallas, 1993), and higher wages and economic success later in life (Elman \& O'Rand, 2004).

Funneling Inequality. A number of metaphors have been used to describe aspects of the college education experience; for example, rivers and bridges represent the college paths of minority and first-generation college students (Goodwin, 2006). According to Turner's concept of educational contest mobility (1960, p. 855), "Elite status is the prize in an open contest, with every effort made to keep lagging contestants in the race until the climax." Rosenbaum (1976) proposed a tournament model to describe the tracking process as one with winners who go on to compete in later competitions and 
losers who drop out altogether. The educational system is perceived as fair because the disadvantaged are socialized to keep hope alive until the end of the competition (Rosenbaum, 1976; Turner, 1960).

The path to educational attainment can also be illuminated by conceptualizing the process as a funnel that filters out disadvantaged students at each stage in the educational process. Dougherty (1987, p. 94) envisions a "funnel-like structure" that describes a three-step process by which community college entrants are hindered from achieving the same level of educational attainment as four-year college entrants. Like the tournament and contest models, students drop out of the funnel "if they fail at any point" (p. 94), although they might reenter later in life.

Building on Dougherty's conceptualization, I apply the funnel metaphor to all students seeking college degrees. At the top, or widest part of the postsecondary education funnel, sit those students considering a college education. Some members of this group are already limited by virtue of their incongruent habitus (Bourdieu, 1973) or their poor academic performance. As the funnel narrows, students must meet certain demands or requirements: apply for admission, take college preparatory classes, and so forth. Those who do not meet these requirements are filtered out of the process, which has the effect of further narrowing the pool of those who hope to receive a degree. Schooling can be seen as a series of transitions, with students moving in stages and making transitions between institutions (Mare, 2001). Although the precise impact of class background may be different at each stage (Mare, 2001), disadvantaged youth exhibit a constellation of characteristics that have an impact on their achievement at every stage of the educational process. There is a cumulative and reinforcing effect of the multiple barriers they face (Elman \& O'Rand, 2004; Walpole, 2003).

Throughout the process, then, advantaged students pursue college in ways that provide them with further advantages later in life. When disadvantaged students pursue more advantaged pathways, such as enrollment at a four-year institution, they do so with higher risks of noncompletion and in the face of multiple barriers to attendance and attainment (Dougherty \& Kienzl, 2006; Walpole, 2003). Viewing the postsecondary education process as a funnel that filters out disadvantaged students at each stage helps us to think about class as an analytical category rather than a variable (Furstenberg, 2006) and to recognize the unique experiences and obstacles facing young adults of different class backgrounds.

Postsecondary Education Enrollment. Although the majority of high school students expect to receive a college degree, many lack basic information about the nature and the amount of education required for particular careers (Schneider \& Stevenson, 1999) or do not accurately assess "whether they are college-bound or work-bound" (Rosenbaum, 2001, p. 20). Why is this the case? Some of the confusion results from a "college for all" approach in the United States, which does not recognize or directly confront barriers to college attainment, such as weak performance and insufficient financial 
resources (Rosenbaum, 2001). The educational system lacks adequate alternatives such as vocational education to the two main options of attaining a high school diploma or four-year college degree (Kerckhoff, 2002). In addition, cultural and social capital influences knowledge of the purposes and requirements of different postsecondary programs as well as the resources to pursue them (McDonough, 1997). Different social classes develop "habiti" that "filter out" college choices that do not fit the "comfort" levels and frames of reference consistent with family, peers, and school resources (McDonough, 1998, p. 186).

First-generation college students are disadvantaged in parental assistance, receiving less help during the application process than those whose parents are college educated (Choy, 2001). Low-income parents are typically pessimistic about their children's educational futures and do not act proactively, although the high perceived efficacy of some families can buffer the negative consequences of disadvantage (Crosnoe, Mistry, \& Elder, 2002). Low-income parents are less likely than affluent parents to financially support their children during young adulthood and offer less assistance when they do provide it (Schoeni \& Ross, 2005). Parental wealth, independent of income, education, or occupation, predicts both college enrollment and attainment (Conley, 2001).

Once a decision to pursue postsecondary education has been made, students need to prepare academically and, if they plan to attend a four-year college, take the SAT or ACT examinations (Choy, 2001). Students then select institutions and submit their applications (Choy, 2001). The last steps prior to enrollment are gaining acceptance, making an institutional choice, and making financial arrangements to pay for their program (Choy, 2001). Once all of this preparation has been completed, students enroll in courses, select majors, achieve academically at an acceptable level, and continue financially covering the costs of their education. In short, students need to persist to attain a degree.

Illustrating postsecondary education funneling, stratification and cumulative disadvantage confront low-income and first-generation college students at each of these stages. Students whose parents did not attend college are less likely than their counterparts to expect to obtain a bachelor's degree and complete the first steps toward college enrollment (Choy, 2001). Although academic performance during high school is a stronger determinant of four-year college enrollment than socioeconomic background, students from more advantaged backgrounds are more likely to complete college preparatory courses and enroll in four-year institutions (Baker $\&$ Velez, 1996). First-generation college students are more likely than other students to be older, come from low-income and disadvantaged racial backgrounds, and have less preparation for college. For example, they have lower grades, lower college entrance exam and senior achievement test scores, and fewer higher-level math courses, which all predict college success and persistence (Chen \& Carroll, 2005; Choy, 2001). Disadvantaged 
class background has the greatest impact on college enrollment rates for academically weak high school students who have not taken college preparatory courses, especially among white students (Baker \& Velez, 1996). Class background is not as influential for academically talented students (Baker \& Velez, 1996).

Stratification Within Institutions. Advantaged students are more likely to attend four-year and elite institutions (Astin \& Oseguera, 2004), boosting their future educational and occupational attainments (Karen, 2002). Fifty-five percent of first-generation college students attended institutions that were two years or less (compared with 35 percent of those whose parents had at least a bachelor's degree) and 38 percent attended four-year colleges ( 57 percent of those whose parents were bachelor's degree recipients did so; see Horn, Nevill, \& Griffith, 2006). Financially dependent community college students are more likely than students at four-year institutions to come from families living below or near the poverty line (Horn et al., 2006).

Low-income community college students are disadvantaged in educational, occupational, and income outcomes (Karen, 2002). Community college enrollment interferes with bachelor's degree attainment as a result of three related funneling processes: a higher dropout rate at community colleges relative to four-year colleges (due to lower academic selectivity and lack of dorms), difficulty transferring to four-year institutions (due to a vocational orientation at community colleges, lack of financial aid, and unfamiliar surroundings), and attrition after transferring to four-year institutions (due to loss of credits, lack of social integration and financial aid, and poorer preparation; see Dougherty, 1987). Community college students from high socioeconomic backgrounds are more likely than their counterparts to successfully transfer to four-year institutions (Dougherty \& Kienzl, 2006).

Social class stratification in educational institutions has increased in the past two decades (Astin \& Oseguera, 2004). Although low-income and firstgeneration college students have gained greater access to higher education, they have not made inroads into the most elite institutions, where only the wealthiest and most educated families have increased their enrollment (Astin $\&$ Oseguera, 2004). First-generation college students are increasingly concentrated in the least selective colleges and universities, even when controlling prior academic achievement during high school (Astin \& Oseguera, 2004).

Patterns of Attendance. Students can also drop out of the postsecondary education funnel due to discontinuous or interrupted attendance, which makes completion of a bachelor's degree less likely (Goldrick-Rab, 2006). First-generation and low-socioeconomic-status (SES) college students are less likely than their counterparts to attend college full time for the entire year and are more likely to attend part time and discontinuously (Chen \& Carroll, 2005). While advantaged students more frequently move from one four-year college to another, disadvantaged students are more likely to leave a four-year institution for a community college (GoldrickRab, 2006) or leave a four-year college altogether (Choy, 2001). 
College Life. First-generation college students are more likely than those whose parents have a college degree to enroll in remedial course work, have difficulty choosing their majors, and trail in the number of credits they complete, even by the first year of college (Chen \& Carroll, 2005). Firstgeneration college students are more likely to major in business, health, and vocational and technical fields (Horn et al., 2006) and to avoid courses in mathematics, science, computer science, social sciences, humanities, history, and foreign languages (Chen \& Carroll, 2005). Their choices may reflect a narrower range of interests or, in cases where colleges link tuition levels to the cost of instruction, an inability to pay for more expensive fields of study. They do not perform as well academically as their more advantaged peers and are more likely to withdraw from or repeat courses (Chen \& Carroll, 2005). Students from low socioeconomic backgrounds study less, are less involved in college life, and report lower grades than their counterparts (Walpole, 2003; Warburton, Bugarin, Nunez, \& Carroll, 2001). Some of these differences may result from students' "voluntary decision" to scale back their commitment as a result of a lack of integration or fit with "the intellectual life" of the college (Baker \& Velez, 1996, p. 92).

Work During College. While the vast majority (nearly 80 percent) of college students work (Horn, Peter, \& Rooney, 2002), low-income students attending two-year institutions work more hours per week than students at other types of institutions (Choy \& Carroll, 2003). At two-year institutions, employed students work an average of thirty-two hours per week, while those in four-year institutions work an average of twenty-six hours per week (Horn et al., 2006). Community college students are more likely than fouryear college students to attend part time and to see themselves as "employees who study" rather than "students who work" (Horn et al., 2006).

Working during college can have both negative and positive consequences. Particularly for nontraditional students, working can lead to difficulty balancing competing demands, interruption in school attendance, low grades, and delayed receipt of degree (Choy, 2001). At the same time, the positive role of work in postsecondary educational attainment should not be discounted. Most obvious is that part-time jobs help college students finance their education. Steady work during high school (more common among advantaged adolescents) may help youth establish effective time management strategies that they draw on during college (Staff \& Mortimer, 2007). Youth identified as having low educational promise during high school tripled their odds of attaining a bachelor's degree with each additional year of higher education combined with part-time work. Working can also help college students with their course work and career preparation (Choy, 2001).

Financial Aid. Tuition costs, which have risen more rapidly than family income, especially for low-income families (Mortenson, 2000), have a bearing on college choices (Merrow, 2007). While the original goal of federal financial aid was to extend higher education access to low-income families, tuition increases and policy changes have recently expanded the goal 
to make college affordable for middle-class families (Choy \& Carroll, 2003). The assumption of policy is that parents will assist students in paying for postsecondary education, although low-income students are increasingly unable to cover these costs (Baker \& Velez, 1996). Despite the positive impact of grants and work-study programs on persistence (Baker \& Velez, 1996), the result of current policy is a reduction in grants and an expansion of loans (Choy \& Carroll, 2003). There has also been movement from needbased to merit-based financial aid at the state level (Mortenson, 2000). At each institution type, low-income students received more federal grants than middle-income students, but they also had more unmet financial need (Choy \& Carroll, 2003).

Attainment. First-generation college students are disadvantaged at the bottom of the postsecondary educational funnel in terms of attainment of a bachelor's degree (Chen \& Carroll, 2005). Of those who began postsecondary education between 1992 and 2000, only 24 percent had attained a bachelor's degree or higher, compared with 68 percent of the students whose parents had at least a bachelor's degree (Chen \& Carroll, 2005). The gap in educational attainment between high- and low-income students has widened, leading Mortenson (2000) to conclude that "higher education has become a tool to preserve and strengthen social stratification." The subjective experiences of postsecondary education, an area to which I now turn, are also characterized by distinct class experiences.

\section{Class Differences in the Subjective Experiences of Postsecondary Education}

While most existing research on class differences in education has focused on objective pathways and attainment, subjective interpretations of educational experiences should also be considered. Consideration of subjective understandings moves beyond descriptions of the type and magnitude of inequalities to elucidate some of "the processes that produce and perpetuate" inequality (Schwalbe et al., 2000, p. 420).

Reproduction of Inequality. Why do young adults construct meanings of their experiences in ways that are consistent with social class reproduction? It has been suggested that high school students use strategies, such as the construction of alternative subcultures (MacLeod, 1995), to cope with their subordinate position (Schwalbe et al., 2000). As working-class youth resist dominant definitions of success by rejecting schooling, they often end up inadvertently reproducing their own class position (MacLeod, 1995).

Working- and middle-class young adults may also conceptualize the goals and purposes of higher education differently. In-depth interviews with Youth Development Study women revealed that those from working-class backgrounds, who disproportionately pursued community college or vocational degrees, emphasized how their schooling prepared them and provided credentials for their subsequent full-time work (see Aronson, 2008). For 
example, one working-class woman who attended a secretarial program at a business college said that her school "really prepared you for what it was going to be like once you started working full time." She contrasted this approach with one that emphasizes identity exploration: "I don't want to go to school and be one of those people [who . . .] takes 15 classes and still doesn't know what they want to do." In contrast, consistent with middleclass expectations, interviewees who attended four-year colleges had always expected to attend college and viewed this experience as a time of selfdevelopment (Aronson, 2008). For many advantaged women, graduating from college was a difficult experience, resulting in a crisis of sorts. To describe their feelings about graduating, they used words like panic, fearful, down, lost, nervous, and frightened, largely because they did not feel like adults (Aronson, 2008).

Class-divergent conceptions of postsecondary education are not just a matter of ability, as low-income and first-generation students experience more conflict about the college application process than their similarly performing counterparts (McDonough, 1997). These students begin to think about going to college later, and their aspirations are more frequently initiated by teachers than by parents (McDonough, 1997). For low-income families, daily survival often takes priority over higher education, which may be seen as "optional" or a "luxury" compared to contributing economically to the household (Lynch \& O'Riordan, 1998, p. 454). Disadvantaged students, particularly those enrolled in elite institutions, may experience culture shock as they confront college expectations or feel distress as they negotiate relationships with students who are different from themselves (Goodwin, 2006). Workingclass students may experience cognitive dissonance as their inner values clash, leading to confusion, anger, shame, and feeling like an "imposter" (Jensen, 2004, p. 171). Students may feel disconnected from their families, or their families may react negatively to their education (Goodwin, 2006). Those who have little exposure to college life often feel fearful or isolated in college, are aware of speaking differently from others, have difficulty making friends, question their own abilities, feel like outsiders, or feel that educational institutions do not understand or respect their experience (Lynch \& O'Riordan, 1998). Students may question their college attendance (Goodwin, 2006).

Identity and Social Transformation. Although postsecondary education overwhelmingly serves to reproduce existing class inequalities, working-class and first-generation college students have the potential to break through class barriers when they persist. Identity transformation occurs as students construct new understandings of who they are in relation to their educations (Stuber, 2006). Jensen (2004) has called this process a "crossover experience" because it represents a break with the past and may lead to new opportunities and learning. A working-class to middleclass identity transformation requires not only self-identification but involves "identity work" strategies, interpersonal acceptance, middle-class role enactments, and adhering to particular scripts (Kaufman, 2003). These 
experiences may be painful and confusing as one's sense of self is altered (Jensen, 2004). Social transformation could result if educational institutions were altered or class inequalities were broken down through the education of disadvantaged young adults. Morrow and Torres (1998, p. 23) point out that there is "at least potential for transformative action" in schools. Given the pervasive inequalities discussed here, such transformations are likely to happen only gradually and incrementally.

\section{Conclusion}

Cumulative disadvantage begins very early in the life course and is extremely tenacious, persisting through all phases of education. I have argued that we should view class differences in postsecondary education as a funneling and filtering process that leads to cumulative disadvantage for workingclass and first-generation college students. Instead of reducing class barriers during the transition to adulthood, the postsecondary educational system is more likely to reproduce existing inequalities.

Directions for Future Research. Many studies assume that college students are already young adults or, more commonly, do not discuss the implications of college experiences for the transition to adulthood. Future research should elucidate the workings of the postsecondary education funnel from a life course perspective, as class-differentiated experiences may vary for older and younger students or those with different life experiences. Future research should also examine the impact of social class on the experience of attending different types of institutions, including factors that enable enrollment and persistence in four-year college programs. We also need research on the intersections between racial and class background and postsecondary education. In addition, we need to more fully evaluate the effectiveness of college interventions, programs, and policies for young adults from different class backgrounds. Finally, the vast majority of research on class differences in postsecondary education has focused on objective patterns of enrollment and attainment. Subjective processes (which include decision making and experiences of opportunities and obstacles) are a black box that has not been fully explored.

Program and Policy Recommendations. Program developers and policymakers should recognize that the transition to adulthood represents a unique phase of the life course that is especially formative for later life course trajectories. As such, interventions and supports should be adapted to the student's other roles and life phase. For example, colleges could expand educational programs through night classes, more flexible programs and requirements, and college reentry programs, among others, and support systems such as advising, workshops, and child care to help full-time workers and parents. Other programs that communicate institutional expectations could be developed to help first-generation students adapt to college life. Developing courses that encourage extracurricular involvement or rela- 
tionships with students of similar backgrounds may also enhance connection to the institution.

Credential-specific educational programming could provide occupational skills relevant to today's economy, especially in growing fields (Kerckhoff, 2002). Our "college for all" culture does not adequately value or use community college and vocational credentials and makes high school seem irrelevant (Rosenbaum, 2001). If other credentials were more widely recognized in the labor market, they would have the potential to promote occupational and wage attainment for those who do not attain a bachelor's degree (Kerckhoff, 2002). We need to expand and develop more formal linkages between postsecondary education and the world of work, such as internships, co-ops, and apprenticeships (Kerckhoff, 2002). It would also be beneficial to develop explicit connections between community colleges and four-year institutions to encourage transfer (for example, articulation agreements).

Financial support for higher education (which has not kept pace with tuition increases; see Schemo, 2007) should be expanded, especially grants and work-study. State support of higher education could include more direct appropriations and an expansion of need-based grants, whose reduction in favor of merit-based aid has been particularly detrimental to low-income students (Mortenson, 2000). Some communities have developed innovative programs; for example, Kalamazoo, Michigan has a scholarship for tuition at public postsecondary institutions for children who attended school within the city and meet minimum grade and attendance requirements. Rigorous high school curricula also can lessen (although not equalize) differences in college access and persistence (Choy, 2001).

The pervasive and deeply rooted nature of class differences means that educational reform needs to move beyond an emphasis on individual motivation to a focus on institutional and social change. To create equality of opportunity for disadvantaged young adults, policymakers usually think about expanding access, equalizing participation and persistence, and achieving greater parity in attainment (Lynch \& O'Riordan, 1998). However, as Lynch and O'Riordan (1998) point out, this approach assumes a meritocratic model of education, where success is measured in terms of effort, ability, and achievement rather than a playing field that is unequal from the start. As Aronowitz and Giroux (1985, p. 174) point out, "Americans have tended, wrongly, to equate equality and equal opportunity." Efforts at educational reform will not, however well intentioned, remove existing disparities. To close these gaps, policy will need to challenge the overwhelming inequalities that underlie our educational and economic systems.

\section{References}

Aronowitz, S., \& Giroux, H. (1985). Education under siege: The conservative, liberal, and radical debate over schooling. Westport, CT: Greenwood Press.

Aronson, P. (2008). The markers and meanings of growing up: Contemporary young women's transition from adolescence to adulthood. Gender and Society, 22(1), 56-82. 
Aschaffenberg, K., \& Maas, I. (1997). Cultural and educational careers: The dynamics of social reproduction. American Sociological Review, 62, 573-587.

Astin, A. W., \& Oseguera, L. (2004). The declining "equity" of American higher education. Review of Higher Education, 27(3), 321-341.

Baker, T., \& Velez, W. (1996). Access to and opportunity in postsecondary education in the United States: A review. Sociology of Education, 69, 82-101.

Ball, S., \& Vincent, C. (2001). New class relations in education: The strategies of the "fearful" middle class. In J. Demaine (Ed.), Sociology of education today (pp. 180-195). New York: Palgrave.

Bourdieu, P. (1973). Cultural reproduction and social reproduction. In R. Brown (Ed.), Knowledge, education and cultural change (pp. 71-112). London: Tavistock.

Bowles, S., \& Gintis, H. (1976). Schooling in capitalist America: Educational reform and the contradictions of economic life. New York: Basic Books.

Bozick, R., \& DeLuca, S. (2005). Better late than never? Delayed enrollment in the high school to college transition. Social Forces, 84(1), 531-554.

Chen, X., \& Carroll, C. D. (2005). First-generation students in postsecondary education: A look at their college transcripts. Washington, DC: National Center for Education Statistics, U.S. Department of Education.

Choy, S. P. (2001). Students whose parents did not go to college. Washington, DC: National Center for Education Statistics, U.S. Department of Education.

Choy, S. P. (2002). Nontraditional undergraduates. Washington, DC: National Center for Education Statistics, U.S. Department of Education.

Choy, S. P., \& Carroll, C. D. (2003). How families of low-and middle-income undergraduates pay for college: Full-time dependent students in 1999-2000. Washington, DC: National Center for Education Statistics, U.S. Department of Education.

Conley, D. (2001). Capital for college: Parental assets and postsecondary schooling. Sociology of Education, 74(1), 59-72.

Crosnoe, R., Mistry, R. S., \& Elder, G. H. Jr.(2002). Economic disadvantage, family dynamics, and adolescent enrollment in higher education. Journal of Marriage and Family, 64(3), 690-702.

Dougherty, K. J. (1987). The effects of community colleges: Aid or hindrance to socioeconomic attainment? Sociology of Education, 60, 86-103.

Dougherty, K. J., \& Kienzl, G. (2006). It's not enough to get through the open door: Inequalities by social background in transfer from community colleges to four-year colleges. Teachers College Record, 108(3), 452-487.

Elman, C., \& O'Rand, A. M. (2004). The race is to the swift: Socioeconomic origins, adult education, and wage attainment. American Journal of Sociology, 110(1), 123-160.

Furstenberg, F. F. (2006, March 23-26). Diverging development: The not so invisible hand of social class in the United States. Paper presented at the biennial meetings of the Society for Research on Adolescence, San Francisco. Available at http://www.transad.pop. upenn.edu.

Furstenberg, F. F., Jr., Kennedy, S., McLoyd, V. C., Rumbaut, R. G., \& Settersten, R. A., Jr. (2004). Growing up is harder to do. Contexts, 3(3), 33-41.

Goldrick-Rab, S. (2006). Following their every move: An investigation of social-class differences in college pathways. Sociology of Education, 17(1), 61-79.

Goodwin, L. L. (2006). Graduating class: Disadvantaged students crossing the bridge of higher education. Albany: State University of New York Press.

Hill, M. S., \& Yeung, W. J. (1999). How has the changing structure of opportunities affected transitions to adulthood? In A. Booth, A. C. Crouter, \& M. J. Shanahan (Eds.), Transitions to adulthood in a changing economy: No work, no family, no future? (pp. 3-39). Westport, CT: Praeger.

Horn, L., Nevill, S., \& Griffith, J. (2006). Profile of undergraduates in U.S. postsecondary education institutions: 2003-04: With a special analysis of community college students: 
Statistical analysis report. Washington, DC: National Center for Education Statistics, U.S. Department of Education.

Horn, L., Peter, K., \& Rooney, K. (2002). Profile of undergraduates in U.S. postsecondary education institutions: 1999-2000. Washington, DC: National Center for Education Statistics, U.S. Department of Education.

Jensen, B. (2004). Across the great divide: Crossing classes and clashing cultures. In M. Zweig (Ed.), What's class got to do with it? American society in the twenty-first century (pp. 168-83). Ithaca, NY: ILR Press.

Karen, D. (2002). Changes in access to higher education in the United States: 1980-1992. Sociology of Education, 75(3), 191-210.

Kaufman, P. (2003). Learning to not labor: How working-class individuals construct middle-class identities. Sociological Quarterly, 44(3), 481-504.

Kerckhoff, A. C. (2002). The transition from school to work. In J. T. Mortimer \& R. W. Larson (Eds.), The changing adolescent experience: Societal trends and the transition to adulthood (pp. 52-87). Cambridge: Cambridge University Press.

Lareau, A. (2003). Unequal childhoods: Class, race, and family life. Berkeley: University of California Press.

Lynch, K., \& O'Riordan, C. (1998). Inequality in higher education: A study of class barriers. British Journal of Sociology of Education, 19(4), 445-478.

MacLeod, J. (1995). Ain't no makin' it: Aspirations and attainment in a low-income neighborhood. Boulder, CO: Westview Press.

Mare, R. D. (2001). Observations on the study of social mobility and inequality. In D. B. Grusky (Ed.), Social stratification (2nd ed., pp. 477-488). Boulder, CO: Westview Press.

McDonough, P. M. (1997). Choosing colleges: How social class and schools structure opportunity. Albany: State University of New York Press.

McDonough, P. M. (1998). Structuring college opportunities: A cross-case analysis of organizational cultures, climates, and habiti. In C. A. Torres \& T. R. Mitchell (Eds.), Sociology of education: Emerging perspectives (pp. 181-210). Albany: State University of New York Press.

McGrath, D., \& Kuriloff, P. J. (1999). "They're going to tear the doors off this place": Upper-middle-class parent school involvement and the educational opportunities of other people's children. Educational Policy, 13(5), 603-629.

Merrow, J. (2007, April 22). The two-year attraction. New York Times, 4A.

Moen, P., \& Orrange, R. M. (2002). Careers and lives: Socialization, structural lag, and gendered ambivalence. In R. A. Settersten Jr. \& T. J. Owens (Eds.), Advances in life course research (pp. 231-306). Amsterdam: Elsevier Science.

Morrow, R. A., \& Torres, C. A. (1998). Education and the reproduction of class, gender, and race: Responding to the postmodern challenge. In C. A. Torres \& T. R. Mitchell (Eds.), Sociology of education: Emerging perspectives (pp. 19-45). Albany: State University of New York Press.

Mortenson, T. G. (2000). Poverty, race, and the failure of public policy: The crisis of access in higher education. Academe, 86(6), 38-43.

Mortimer, J. T. (2003). Working and growing up in America. Cambridge, MA: Harvard University Press.

Pallas, A. M. (1993). Schooling in the course of human lives: The social context of education and the transition to adulthood in industrial society. Review of Educational Research, 63(4), 409-447.

Rosenbaum, J. E. (1976). Making inequality: The hidden curriculum of high school tracking. Hoboken, NJ: Wiley.

Rosenbaum, J. E. (2001). Beyond college for all: Career paths for the forgotten half. New York: Russell Sage Foundation.

Schemo, D. J. (2007, June 10). With few limits and high rates, private loans deepen student-debt crisis. New York Times, 22. 
Schneider, B., \& Stevenson, D. (1999). The ambitious generation: America's teenagers, motivated but directionless. New Haven, CT: Yale University Press.

Schoeni, R. F., \& Ross, K. E. (2005). Material assistance from families during the transition to adulthood. In R. A. Settersten Jr., F. F. Furstenberg Jr., \& R. G. Rumbaut (Eds.), On the frontier of adulthood: Theory, research, and public policy (pp. 396-416). Chicago: University of Chicago Press.

Schwalbe, M., Godwin, S., Holden, D., Schrock, D., Thompson, S., \& Wolkomir, M. (2000). Generic processes in the reproduction of inequality: An interactionist analysis. Social Forces, 79(2), 419-452.

Staff, J., \& Mortimer, J. T. (2007). Educational and work strategies from adolescence to early adulthood: Consequences for educational attainment. Social Forces, 85(3), 1169-1194.

Stuber, J. M. (2006). Talk of class: The discursive repertoires of white working- and upper-middle-class college students. Journal of Contemporary Ethnography, 35(3), 285-318.

Tanner, J., \& Yabiku, S. (1999). Conclusion: The economies of young adulthood-One future or two? In A. Booth, A. C. Crouter, \& M. J. Shanahan (Eds.), Transitions to adulthood in a changing economy: No work, no family, no future? (pp. 254-68). Westport, CT: Praeger.

Turner, R. H. (1960). Sponsored and contest mobility and the school system. American Sociological Review, 25(6), 855-867.

U.S. Census Bureau. (2003). Educational attainment: 2000. Washington, DC: U.S. Department of Commerce.

Walpole, M. (2003). Socioeconomic status and college: How SES affects college experiences and outcomes. Review of Higher Education, 27(1), 45-73.

Warburton, E. C., Bugarin, R., Nunez, A., \& Carroll, C. D. (2001). Bridging the gap: Academic preparation and postsecondary success of first-generation students. Washington, DC: National Center for Education Statistics, U.S. Department of Education.

PAMELA ARONSON is an assistant professor of sociology at the University of Michigan-Dearborn. 